\title{
Metastatic Papillary Thyroid Cancer in Tuberculous Lymphadenopathy: An Unfortunate Dual Pathology
}

\author{
Tüberküloz Lenfadenopatisinde Metastatik Papiller Tiroid Kanseri: Beklenmeyen Dual Patoloji
}

\section{Nornazirah Azizan ${ }^{1}$, Firdaus Hayati ${ }^{2}$, Nor Faezan Abdul Rashid ${ }^{3}$, Shahrun Niza Abdullah Suhaimi ${ }^{4}$}

${ }^{1}$ Department of Pathobiology and Medical Diagnostic, Faculty of Medicine and Health Sciences, Universiti Malaysia Sabah, Malaysia

2 Department of Surgery, Faculty of Medicine and Health Sciences, Universiti Malaysia Sabah, Malaysia

${ }^{3}$ Department of General Surgery, Surgical Sciences Cluster, Faculty of Medicine, Universiti Teknologi MARA, Selangor, Malaysia

${ }^{4}$ Department of Surgery, Hospital Canselor Tuanku Muhriz, Universiti Kebangsaan Malaysia, Kuala Lumpur, Malaysia

\section{ABSTRACT}

Papillary thyroid carcinoma usually spreads through lymphatic route, presents as regional lymphadenopathy similar to extra-pulmonary tuberculosis of the cervical regions. We report the case of a 77-year-old woman with synchronous coexistence of tuberculosis and metastatic carcinoma in dissected lymph nodes. Total thyroidectomy is the standard care of treatment with additional neck dissection in clinically positive neck nodes. In the endemic areas and previous history of tuberculosis contact, the possibility of synchronous co-occurrence of these two pathologies should be considered thus anti-tuberculous treatment can be initiated concurrently.

Key Words: Papillary thyroid carcinoma, tuberculosis, extra-pulmonary tuberculosis, cervical lymphadenopathy, metastatic carcinoma

Accepted: 03.09 .2018
ÖZET

Papiller tiroid karsinomu genellikle lenfatik yoldan yayılır, servikal bölgelerin ekstrapulmoner tüberkülozuna benzer bölgesel lenfadenopati olarak ortaya çıkar. Bu yazıda, distal lenf nodlarında tüberküloz ve metastatik karsinomun eşzamanlı birlikteliği olan 77 yaşında bir kadın hasta sunuldu. Total tiroidektomi, klinik olarak pozitif boyun nodüllerinde ek boyun diseksiyonu ile tedavi standart tedavidir. Endemik bölgelerde ve daha önceki tüberküloz teması öyküsünde, bu iki patolojinin eşzamanlı birlikte oluşma ihtimali göz önünde bulundurulmalı, böylelikle anti-tüberküloz tedavi eşzamanlı olarak başlatılabilir.

Anahtar Sözcükler: Papiller tiroid kanser, tüberküloz, ekstrapulomoner tüberküloz, servikal lenfadenopati, metastatik kanser

Geliş Tarihi: 11.02.2018

Kabul Tarihi: 09.03.2018

\section{INTRODUCTION}

Papillary thyroid carcinoma (PTC) is the commonest cause of welldifferentiated thyroid malignancy arises from the follicular epithelium. It accounts for more than $80 \%$ of primary thyroid neoplasm (1). PTC commonly spreads through lymphatic channel to the regional lymph nodes; therefore among $23-56 \%$ of the patients are found to have cervical nodes metastasis upon initial presentation (2). Tuberculosis is routinely associated with lymph nodes involvement whereas cervical lymphadenopathy is the most common clinical presentation of extra-pulmonary TB. It develops in $11 \%$ of the cases especially in endemic region and previous history of TB contact (3). Besides lymph nodes, extra-pulmonary TB can happen in various organs in the body including breast, thyroid, and even anus (4).

Since primary and secondary metastatic malignancies manifest as lymphadenopathy, similar lymph nodes presentation in the neck may create an enigma to the attending physician (3). Herein, we report an unfortunate case of synchronous existence of tuberculosis and metastatic carcinoma in cervical lymph nodes identified in a final histologic specimen after neck dissection of PTC.

\section{CASE REPORT}

A 77-year-old woman came to our attention with complaint of cough and fever for 1 week associated with shortness of breath. In addition, she also claimed to have an anterior neck swelling for the past 4 years. She denied compressive symptoms, voice hoarseness, hyperthyroid or hypothyroid symptoms. There was no night sweat, loss of weight, or contact with pulmonary TB.

Upon presentation, she was not septic but was slightly tachypneic with respiratory rate of 20 breathe per minute and oxygen saturation of $95 \%$ under room air. There was minimal crepitation on both lower zones. An anterior neck swelling was felt with left was larger than the right, firm in consistency and moved with swallowing. In addition, there was presence of enlarged lymph nodes along the bilateral jugular chains. Biochemical investigations revealed leukocytosis with normal biochemical profile. Arterial blood gases were within normal range. Thyroid function test revealed no abnormality. She was treated as community-acquired pneumonia. 
Surprisingly, chest radiograph revealed a small cannon ball lesion that represented lung metastases. Ultrasound of the neck revealed a left dominant nodule with multinodular goitre. Sonographically, there was an irregular hypoechoic lesion, $3 \times 3 \mathrm{~cm}$, with intranodular vascularity and microcalcification. These features were suggestive of malignancy. Computed tomography (CT) showed thyroid cancer with lymphadenopathy and extensive lung metastasis. Fine needle aspiration cytology of the thyroid revealed a suspicion of papillary thyroid cancer.

A total thyroidectomy with central, both lateral neck dissections were performed. Grossly, the outer surface was smooth but lobulated. Serial section of the larger lobe had tan solid cut surface measuring $45 \times 40 \times 32 \mathrm{~mm}$ in a surrounding multiple varied sizes colloid rich nodules displaying areas of fibrosis, cystic changes and haemorrhage. Cut section of the smaller lobe showed 2 solid areas measuring $32 \times 25 \times 24 \mathrm{~mm}$ and $8 \times 7 \times 5 \mathrm{~mm}$ at upper pole. All solid areas in both thyroid lobes were less than $1 \mathrm{~mm}$ from the thyroid capsule.

Final histology was consistent with multifocal PTC, follicular variant with areas of tumour dedifferentiation (largest was $45 \mathrm{~mm}$ in diameter). The tumour cells consisted of overlapping nuclei displaying intranuclear grooves. All tumour foci were very near to the thyroid capsule, which was less than $1 \mathrm{~mm}$ distance. Lymphovascular invasion was seen as well. Nodal metastases were seen in 6 out of 76 regional lymph nodes harvested from the lateral group (Figure 1 and 2). Some of the lymph nodes show presence of synchronous lesion of PTC and granulomas (Figure 2). Most of the other lymph nodes exhibit evidence of caseating granulomatous lymphadenitis with Langhan's giant cells (Figure 3).

She had a good postoperative recovery. However, a month later, there was two lymph nodes appeared at the right level II. Excision biopsy was performed and histologically confirmed to be recurrent PTC. She was subjected for radioactive remnant ablation and had thyroxine suppressive therapy. In view of extra-pulmonary TB, she was started on anti-tuberculous therapy Akurit-4 for 6 months and is under Infectious Disease Team for regular follow up.

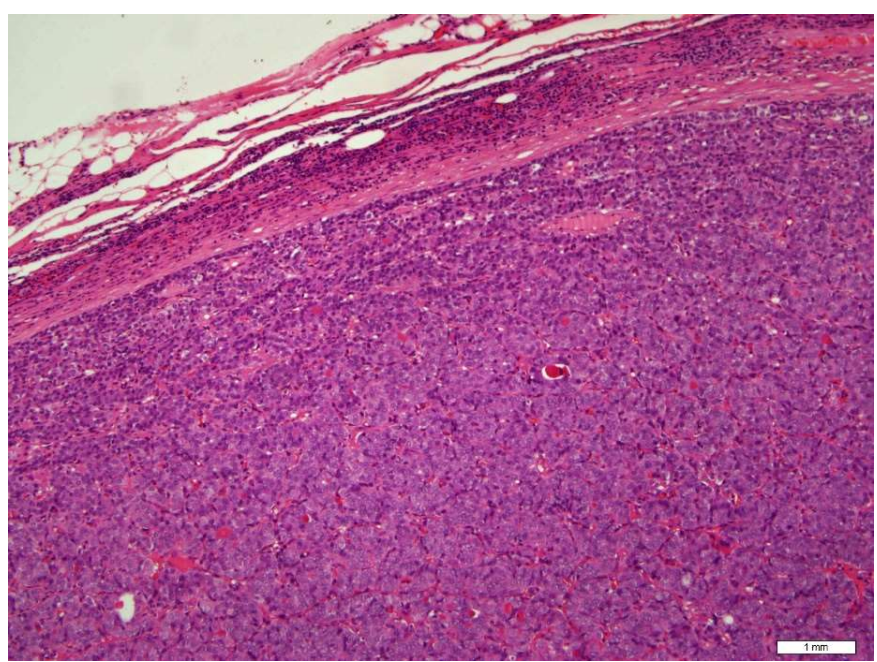

Figure 1: Encapsulated lymph node with total effacement of normal architecture infiltrated by papillary thyroid carcinoma cells

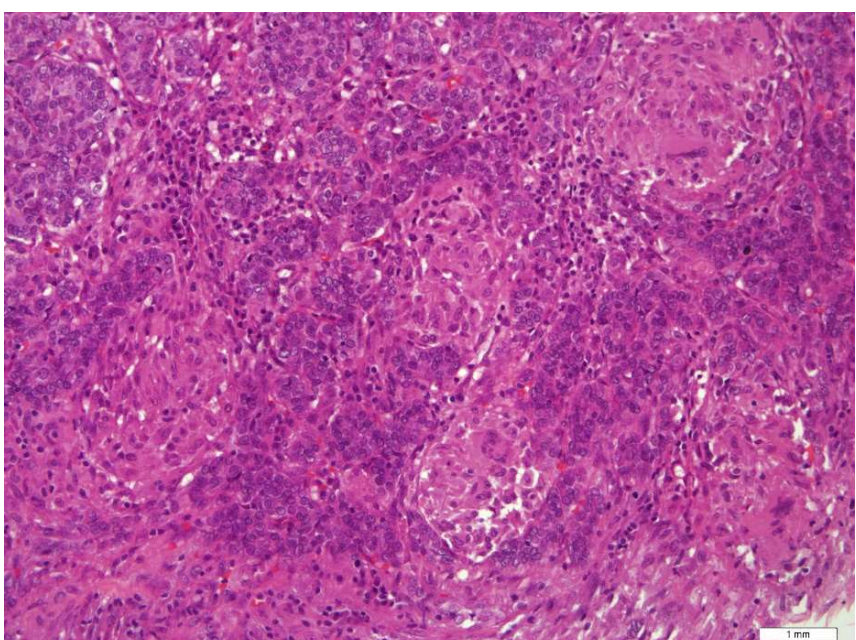

Figure 2: Synchronous lesions of PTC and granuloma within the same lymph node

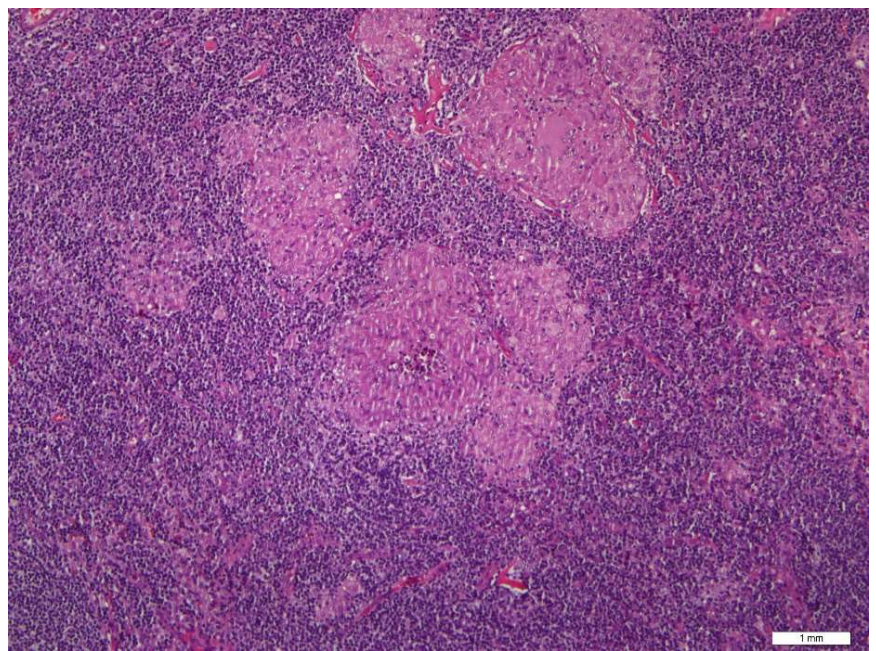

Figure 3: Presence of caseating granuloma with background of lymphoid tissues

\section{DISCUSSION}

Tuberculosis is a chronic granulomatous disease, caused by Mycobacterium tuberculosis. It has caused major health concern worldwide, primarily in developing countries. In Malaysia, TB fell as the second most common aetiology of communicable disease in year 2001 (3). This number has been increasing in recent years due to influx of migrating population from neighbouring countries and raising cases of immunodeficient patients such as human immunodeficiency virus.

PTC commonly spreads through lymphatic channel to the regional lymph nodes. Hence, the presence of cervical lymph nodes is always being neglected for TB. It is usually indistinguishable since the appearance and distribution of the pathologic lymph nodes tend to be identical. Rarely, PTC has tendency to spread via haematogenous route especially in follicular variant. In endemic areas and previous history of pulmonary TB contact, tuberculous lymphadenopathy has always been considered as the primary aetiology of enlarged lymph nodes.

Many literatures have explored the issues pertaining to tuberculous lymphadenopathy mimicking metastatic lymph nodes from PTC $(5,6)$. The final histopathology of the dissected cervical lymph nodes showed presence of TB, but surprisingly no existing metastasis (7). However, very few literatures have discussed the synchronous coexistence between tuberculous and metastatic lymph nodes as summarized in Table 1. 
Table 1. Summary of cases in metastatic papillary thyroid carcinoma with tuberculous lymphadenopathy

\begin{tabular}{|c|c|c|c|c|c|c|c|}
\hline $\begin{array}{l}\text { Age (yr) / } \\
\text { gender }\end{array}$ & $\begin{array}{l}\text { Authors / Yr } \\
\text { of Publication }\end{array}$ & $\begin{array}{l}\text { Presenting } \\
\text { Symptoms }\end{array}$ & Imaging and Findings (if done) USG or CT & Surgery & HPE & $\begin{array}{l}\text { Metastatic Lymph } \\
\text { Nodes }\end{array}$ & Treatment \\
\hline 77 / female & Present case & $\begin{array}{l}\text { Cough and fever } \\
\text { with underlying } \\
\text { anterior neck } \\
\text { swelling }\end{array}$ & $\begin{array}{l}\text { USG }=3 \mathrm{~cm} \text { left dominant thyroid nodule. } \\
\mathrm{CT}=\text { thyroid cancer with lymphadenopathy } \\
\text { and extensive lung metastasis }\end{array}$ & $\begin{array}{l}\text { Total thyroidectomy } \\
\text { with central, both } \\
\text { lateral neck dissection }\end{array}$ & $\begin{array}{l}\text { Multifocal } \\
\text { PTC, } \\
\text { follicular } \\
\text { variant }\end{array}$ & $\begin{array}{l}6 \text { out of } 76 \\
0 / 21 \text { positive nodes } \\
\text { (central group) } \\
6 / 55 \text { positive nodes } \\
\text { (lateral group) }\end{array}$ & $\begin{array}{l}\text { Radioactive iodine } \\
\text { therapy; ATB } \\
\text { treatment for } 6 \\
\text { months }\end{array}$ \\
\hline 26 / female & $\begin{array}{l}\text { Swathanthra } \\
\text { et al } 8 / 2014\end{array}$ & $\begin{array}{l}\text { Anterior right } \\
\text { neck swelling } \\
\text { with dysphagia }\end{array}$ & $\begin{array}{l}\text { USG = benign looking nodule in the right } \\
\text { lobe with cervical lymphadenopathy. } \\
\text { CT = a well-defined solitary nodule in the } \\
\text { right lobe of the thyroid with enlarged } \\
\text { necrosed right cervical lymph nodes. }\end{array}$ & $\begin{array}{l}\text { Subtotal thyroidectomy } \\
\text { with central and right } \\
\text { lateral neck dissection }\end{array}$ & PTC & $\begin{array}{l}4 \text { out of } 23 \\
2 / 2 \text { positive nodes } \\
\text { (central group) } \\
2 / 21 \text { positive nodes } \\
\text { (lateral group) }\end{array}$ & $\begin{array}{l}\text { Radioactive iodine } \\
\text { therapy; ATB } \\
\text { treatment for } 6 \\
\text { months }\end{array}$ \\
\hline 61 / female & $\begin{array}{l}\text { Kafadar et al } \\
\text { / } 2017\end{array}$ & $\begin{array}{l}\text { Anterior } \\
\text { swelling }\end{array}$ & $\begin{array}{l}\text { USG }=\text { diffuse milimetric calcifications } \\
\text { measuring } 4 \mathrm{~cm} \text { at the lateral portion of the } \\
\text { left thyroid lobe. Lymph nodes in the left } \\
\text { jugulo-digastric region }\end{array}$ & $\begin{array}{l}\text { Total thyroidectomy } \\
\text { with central and left } \\
\text { lateral neck dissection }\end{array}$ & $\begin{array}{l}\text { PTC, } \\
\text { diffuse } \\
\text { sclerosing } \\
\text { variant }\end{array}$ & $\begin{array}{l}13 \text { out of } 16 \\
3 / 3 \text { positive nodes } \\
\text { (central group) } \\
10 / 13 \text { nodes (lateral } \\
\text { group) }\end{array}$ & $\begin{array}{l}\text { Radioactive iodine } \\
\text { therapy; ATB } \\
\text { treatment for } 6 \\
\text { months }\end{array}$ \\
\hline
\end{tabular}

$\mathrm{Yr}=$ year; USG = ultrasonography; $\mathrm{CT}$ = computed tomography; $\mathrm{HPE}=$ histopathologic examination; PTC = papillary thyroid carcinoma; $\mathrm{ATB}=$ anti-tuberculosis

Ideally, lymphatic flow of PTC will drain from central to lateral group. This pathophysiology was pictured in lymph nodes dissection by Swathanthra and Kafadar et al but not in ours $(8,9)$. Most metastases were identified in lateral group but none in central group. This patient also depicted the most abundant lymph nodes harvest compared to another two cases, which were $76 \mathrm{lymph}$ nodes. The findings indicated the burden of the disease itself to the lymph nodes.

Suspicious looking lymph nodes that harbour TB are very similar to metastatic PTC sonographically. The lymph nodes tend to be rounded rather than oval with hypoechoic lesions, presence of intranodal cystic necrosis and calcification (10). The nodes are enlarged more than $10 \mathrm{~mm}$ with loss of fatty hilum. Invariably, they have peripheral rim enhancement with irregularly thickened wall (10). FNAC or excision biopsy is indicated if such suspicious lymph nodes identified. In addition, CT only reveals necrosed or calcified lymph nodes.

The use of FNAC in diagnosing tuberculous lymphadenopathy is paramount. It carries a sensitivity and specificity of $88 \%$ and $96 \%$ respectively (11). The FNAC specimens commonly show aggregates of epitheloid histiocytes and caseous necrosis with occasional presence of acid-fast bacilli (AFB). These features are pathognomonic of TB. Furthermore, the diagnostic confirmation will be enhanced by Ziehl-Neelsen staining or after culture by Lowenstein-Jensen media.

Total thyroidectomy is the recommended choice of treatment in PTC patients. In clinically positive neck nodes, an additional neck dissection is the current standard of care (12). This practice is vital in order to ensure better oncologic outcome by enhancing the effect of radioactive remnant ablation as well as the thyroxine suppression therapy. However, neck dissection is not without its complications that include injury to the recurrent laryngeal nerve, phrenic nerve injury, trachea and oesophagus. Extensive evaluation pre and intra operatively is necessary to avoid such complications after a neck dissection. Among measures that can be taken include frozen section of the suspicious lymph nodes.

\section{CONCLUSION}

PTC and TB are routinely associated with cervical lymphadenopathy. Imaging alone is indistinguishable between these two entities. In the endemic areas and previous history of TB contact, the possibility of synchronous existences of these two pathologies should be considered.
Conflict of interest

No conflict of interest was declared by the authors.

\section{REFERENCES}

1. Schlumberger MJ. Papillary and follicular thyroid carcinoma. N Engl J Med 1998;338:297-306

2. Choi EC, Moon WJ, Lim YC. Tuberculous cervical lymphadenitis mimicking metastatic lymph nodes from papillary thyroid carcinoma. $\mathrm{Br} J$ Radiol 2009;82:e208-11

3. Swarma NY. A review of tuberculosis research in Malaysia. Med J Malaysia 2014;69:88-102

4. Sultan $\mathrm{MAH}$, Hayati $\mathrm{F}$, Azizan $\mathrm{N}$, et al. Various presentations of breast tuberculosis and tuberculous lymphadenopathy: A case series of surgical rarity. Med Med J 2017;32:33-41

5. Özkan Z, Akyiğit A, Sakallioğlu Ö, et al. Diagnostic challenge in papillary thyroid carcinoma with cervical lymphadenopathy, metastasis, or tuberculous lymphadenitis. J Craniofac Surg 2013;24:2200-3

6. Kim SM, Jun $\mathrm{HH}$, Chang $\mathrm{HJ}$, et al. Tuberculosis cervical lymphadenopathy mimics lateral neck metastasis from papillary thyroid carcinoma. ANZ J Surg 2016;86:495-8

7. Meng L, Hu S, Huang L, et al. Papillary thyroid cancer coexisting with thyroid tuberculosis: A case report. Oncol Lett 2014;7:1563-5

8. Swathanthra $\mathrm{N}$, Jyothi $\mathrm{C}$, Premalatha $\mathrm{P}$, et al. Papillary carcinoma of thyroid with an unusual coexistence of metastatic deposits and tuberculosis in the cervical lymph nodes. Med J DY Patil Univ 2014;7:59-61

9. Kafadar MT, Miryaguboğlu AM, Değirmencioğlu G, et al. Unexpected finding in the neck dissection specimen of papillary thyroid carcinoma: Concurrence of metastatic deposits and tuberculosis: Case report. Turkiye Klinikleri J Case Rep 2017;25:42-6

10. Ito $\mathrm{T}$, Saito $\mathrm{H}$, Kishine $\mathrm{N}$, et al. Preoperatively diagnosed case with coexistence of papillary thyroid carcinoma and cervical tuberculous lymphadenitis. Int J Surg Case Rep 2015;15:74-7

11. Chao SS, Loh KS, Tan KK, et al. Tuberculous and non-tuberculous cervical lymphadenitis: a clinical review. Otolaryngol Head Neck Surg 2002;126:176-9

12. Yu MG, Atun JM. Tuberculous lymphadenitis mimicking nodal metastasis in follicular variant papillary thyroid carcinoma. Case Reports in Medicine 2016;5623104:3 